\title{
REHABILITATION OF ABANDONED SALTWORKS TO MAXIMIZE CONSERVATION, ECOTOURISM AND WATER TREATMENT POTENTIAL
}

\author{
T.L. CRISMAN ${ }^{1}$ \\ V. TAKAVAKOGLOU ${ }^{2}$ \\ T. ALEXANDRIDIS ${ }^{2}$ \\ V. ANTONOPOULOS \\ G. ZALIDIS ${ }^{2, *}$
}

\author{
${ }^{1}$ Howard T. Odum Center for Wetlands \\ Department of Environmental Engineering Sciences \\ University of Florida, USA \\ ${ }^{2}$ Laboratory of Applied Soil Science, \\ Faculty of Agriculture, Aristotle University of Thessaloniki
}

Greece

Received: $12 / 12 / 08$

*to whom all correspondence should be addressed:

Accepted: $30 / 12 / 08$

e-mail: zalidis@agro.auth.gr

\begin{abstract}
Numerous saltworks have been abandoned throughout the Greek islands and mainland as operations have decreased in number and increased in size. Such areas have great potential for serving the broader society if rehabilitated correctly. Changes in landscape uses recently, especially agricultural practices and rapid expansion of vacation homes and resorts in the islands, have increased nutrient and sediment loading to coastal bays. Previously, streams were diverted around saltworks on the coast to avoid contamination of the salt produced. Rehabilitation of saltworks to accept stream input has great potential to treat nutrient and other contamination from the landscape via natural biological processes of the ecosystem, thus reduce loading to coastal areas and potential contamination of resort beaches. Successfully rehabilitated saltworks will also provide enhanced nature conservation areas that can become part of regional networks of ecotourism opportunities. Examples of the potential for integrating rehabilitated saltworks within both the landscape and regional economy of Greece will be discussed.
\end{abstract}

KEYWORDS: Saltworks, Restoration, Water treatment, Economy, Landscape

\section{HISTORY OF SALTWORKS AND CURRENT STATUS}

In the Mediterranean, there are more than 170 salinas in 18 countries. Of the 90 active salinas, $75 \%$ are located in northern and central Mediterranean countries, Spain, Greece, Italy, France and Portugal constitute $77 \%$, while the remaining countries have fewer than 10 active salinas each. Traditional salinas and small saltworks in the Mediterranean have been in continuous decline since the 1950s. Salt production has undergone a major transformation during the past two centuries (Crisman, 1999). Although mechanization, especially development of high volume pumps, led to an expansion in the overall extent of salinas during the nineteenth century, this trend was reversed in the twentieth century associated with increased efficiency and product quality in emerging large-scale operations and an associated economic failure for small operations (Sadoul et al., 1998).

Today, even large saltworks are threatened, especially those estimated as less competitive than expected: they cease salt production, as a first step to acheive a more profitable function and profile. In Greece, the surface area of operating saltworks has been reduced by $50 \%$ during the last $40-50$ years (Figure 1 ). 


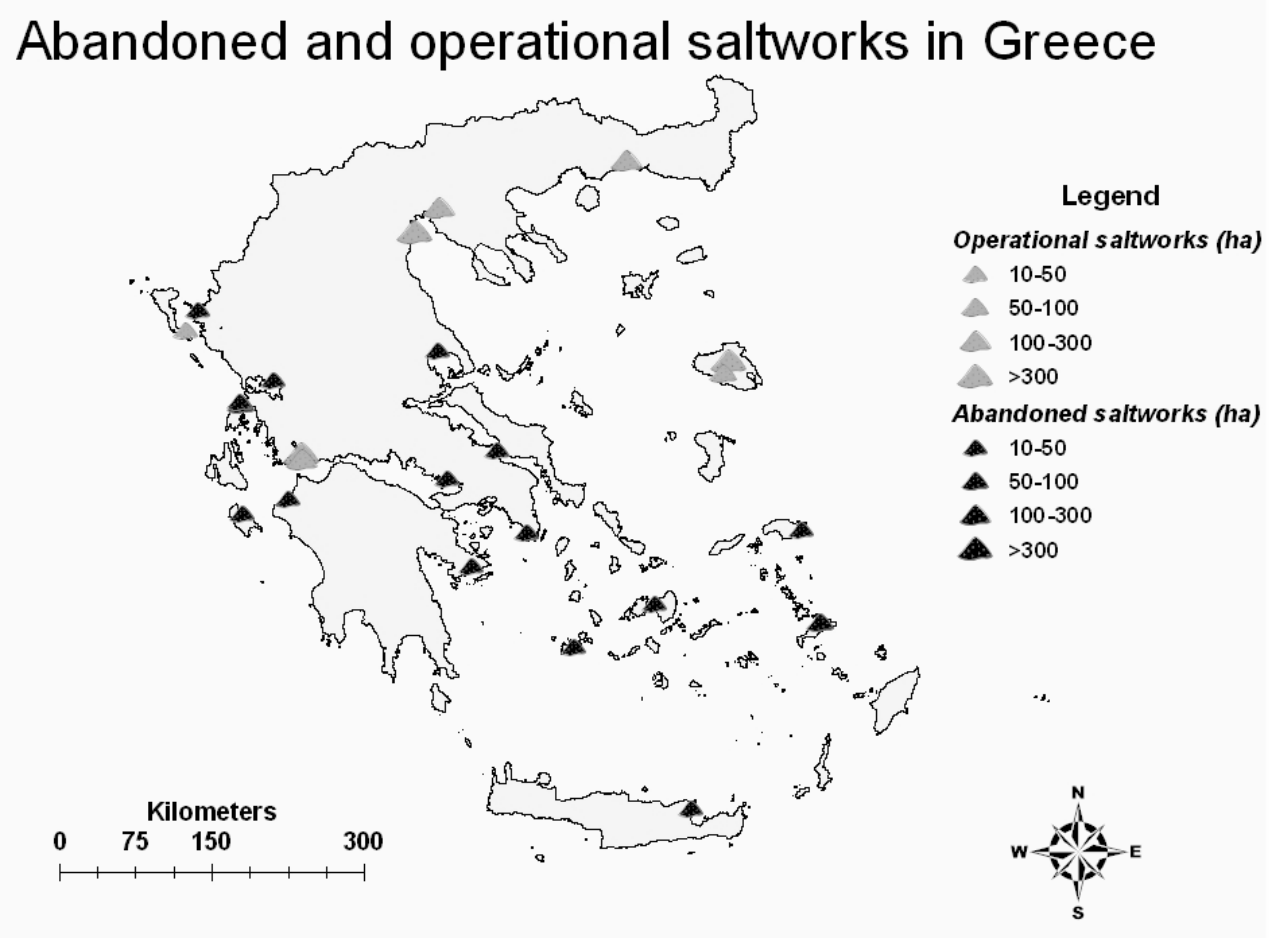

Figure 1. Abandoned and operational saltworks in Greece

At the beginning of 20th century, there were 16 saltworks, fairly small with low production, operating in Greece. From 1920 to 1930, the number of active saltworks increased to 25, and most became more productive by adopting an operating system utilizing continuous crystallisation. Upgrading continued until the 1950s and involved reconstruction of major saltworks including Messolonghi and Kalloni. Beginning in the 1950s, the number of saltworks decrease progressively. By 1986, only 12 of the total 28 Greek saltworks were in operation, and currently, only eight are functional (Petanidou, 2000).

Although saltworks are of ecological, economic and cultural importance, their number is steadily declining. However, abandoned and degraded saltworks may be rehabilitated and transformed into systems of high biological value and economic activity. The aim of this paper is to underline the importance of abandoned saltworks rehabilitation as part of the landscape and regional economy.

\section{THE FATE OF SALTWORKS AFTER ABANDONMENT}

In general, abandonment of saltworks results in a complete change in land use. In case of Lefkas Island in Greece for example, the abandonment of saltworks in the north part of the island is related to the expansion of agricultural and urban (artificial) areas (Figure 2ab). Abandoned saltworks are transformed into rice fields, fish farms or even oyster farms as in western France. Abandoned saltworks are found throughout Greece and include both large saltworks as well as small salinas of local interest. Such large saltworks rarely maintain their characteristics and ecological importance, and most are progressively losing, or even already lost, their ecological value. Some have completely disappeared due to drastic change in land use (industrialization, urbanization), including the saltworks of Volos, which have been completely urbanised (Petanidou, 2000). Other abandoned saltworks, such as the Kopanas saltworks, have gradually degraded as a result of solid waste disposal. 
However, if proper hydrological conditions exist, former saltworks, such as those of Samos, potentially can be restored. This is especially true for abandoned, small artisanal saltworks located on low-lying sandy shores where periodic connection with the sea maintains some of their ecological characteristics.

\section{IMPORTANCE OF ABANDONED SALTWORKS TO THE LANDSCAPE AND REGIONAL ECONOMY}

Mediterranean saltworks are both highly modified natural and created coastal ecosystems. Saltworks are integrated ecosystems that can effectively produce an economically viable product while serving a critical role in nature conservation and biodiversity (Korovessis and Lekkas, 1999). In addition, both saltworks and salinas are part of the cultural heritage of the Mediterranean and when properly managed, play an important and sustainable socioeconomic role at the family and village scale. With proper management of the hydrology, water is available to these ecosystems throughout the dries portions of the year, the unpredictable and usually dry spring and summer. The food web that tolerates the elevated salinity of saltworks and salinas can be highly productive and provide a key food source for a wide variety of resident and migratory birds (Britton and Johnson, 1987; Sadoul et al., 1998).

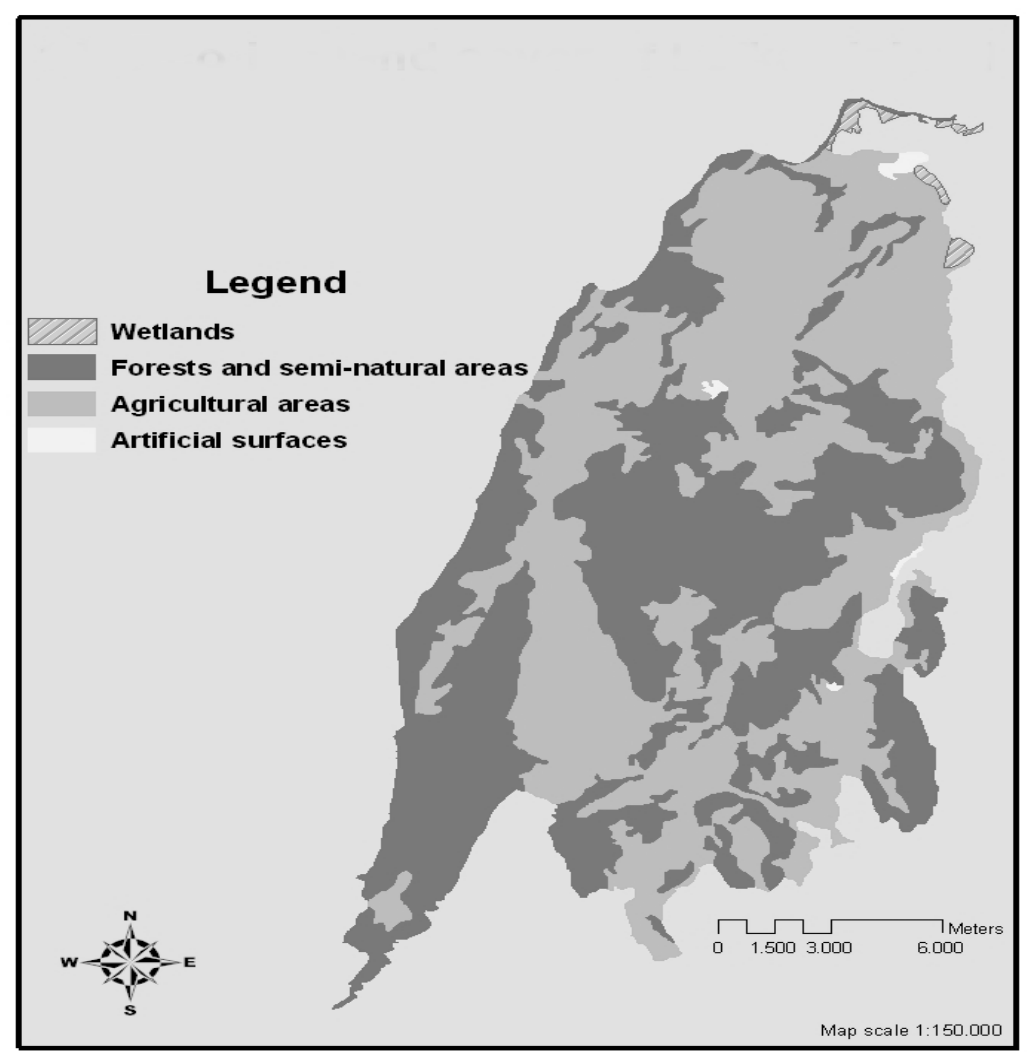

Figure 2a. CORINE Land Cover of Lefkas Island in 1990

In addition, because of their usually highly controlled accessibility, salinas provide maximum protection of birds for feeding and breeding. Although the coastlines of most the Mediterranean basin have been severely altered via urbanisation and industrialisation, salinas can provide a positive benefit for landscape management, nature conservation and the local and regional economy. 


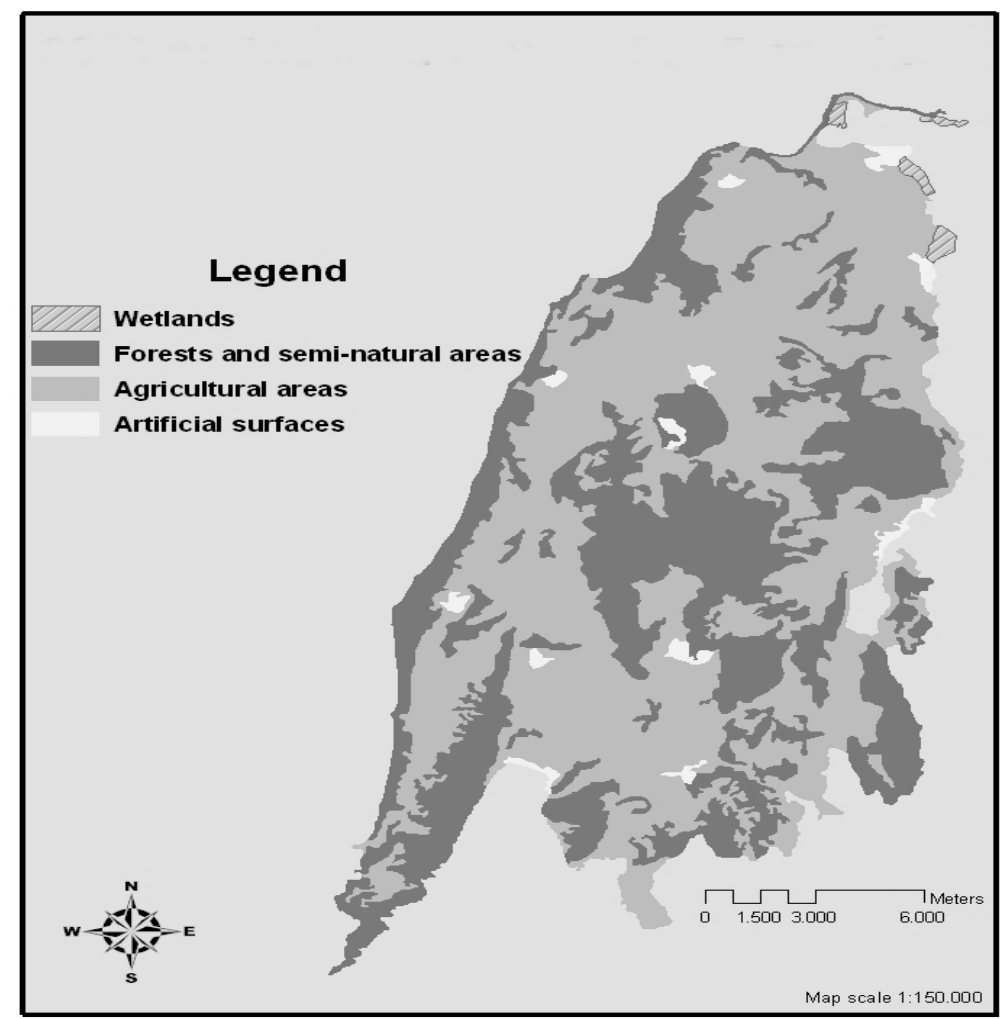

Figure $2 b$. CORINE Land Cover of Lefkas Island in 2000

Abandoned saltworks can provide a vast array of benefits to humans via goods (products) and services (functions). Since few of these are traded in the market-place, they rarely have a readily observable monetary or financial value. However, they can have a considerable socio-economic value, particularly when utilised on a sustainable basis. Saltwork rehabilitation schemes should in theory be able to re-introduce many, if not all, of the benefits associated with them. There are several ways of categorising the full range of benefits attributable to different habitats (Pearce and Turner, 1990; Barton, 1994). Possibly the most comprehensive and appropriate is based on Total Economic Value, which comprises direct and indirect use and non-use values (Spurgeon, 1998). The main categories of environmental benefits for abandoned saltworks are outlined in Table 1.

As a means of maintaining global biodiversity, increased attention is being paid to rehabilitating and creating a variety of coastal habitats including saltworks as wetlands high ecological value. Several Greek saltworks (e.g. Messolonghi, Kitros, among others) are considered of international importance according to the Ramsar Convention and include priority habitats and targeted species protected by European and international agreements on nature conservation (Zalidis and Mantzavelas, 1995; Walmsley, 1999).

In addition, many saltworks have historical and cultural value. Several have been the site of significant historical events, making them living museums within the landscape. Saltworks can also have ethnological value associated with architectural aspects of the salinas, traditional ways of production and equipment used, working and social conditions of the people employed in salt making, and even the product itself as a cultural element (Petanidou 1997; 2000).

During the last decade, there has been an increasing trend of considering salinas as a tourist destination to promote private and public enterprises focused on ecotourism, both traditional and alternative (Neves, 2002). Salinas possess numerous ecological, cultural and historical values that can be utilized for tourism purposes. However, the importance of saltworks goes 
far beyond simple tourism, since they are able to play additional multiple roles within the landscape and local economy.

The ability of saltworks, as wetland ecosystems, to improve water quality is often overlooked (Kadlec and Knight, 1996). All or part of abandoned saltworks can be easily converted into treatment areas for water quality improvement and pollution control. In general, wetland areas are able to perform functions related to sediment/toxicant trapping, and nutrient removal and transformation. Application of principles of ecological and environmental engineering, such as establishing wetland buffer zones for non-point source pollution control and/or creation of constructed wetlands for point source pollution control, may maximize the performance of wetland functions related to water quality improvement, and transform abandoned saltworks into natural systems for water treatment.

Table 1. Categories of environmental benefits (DoE, 1996)

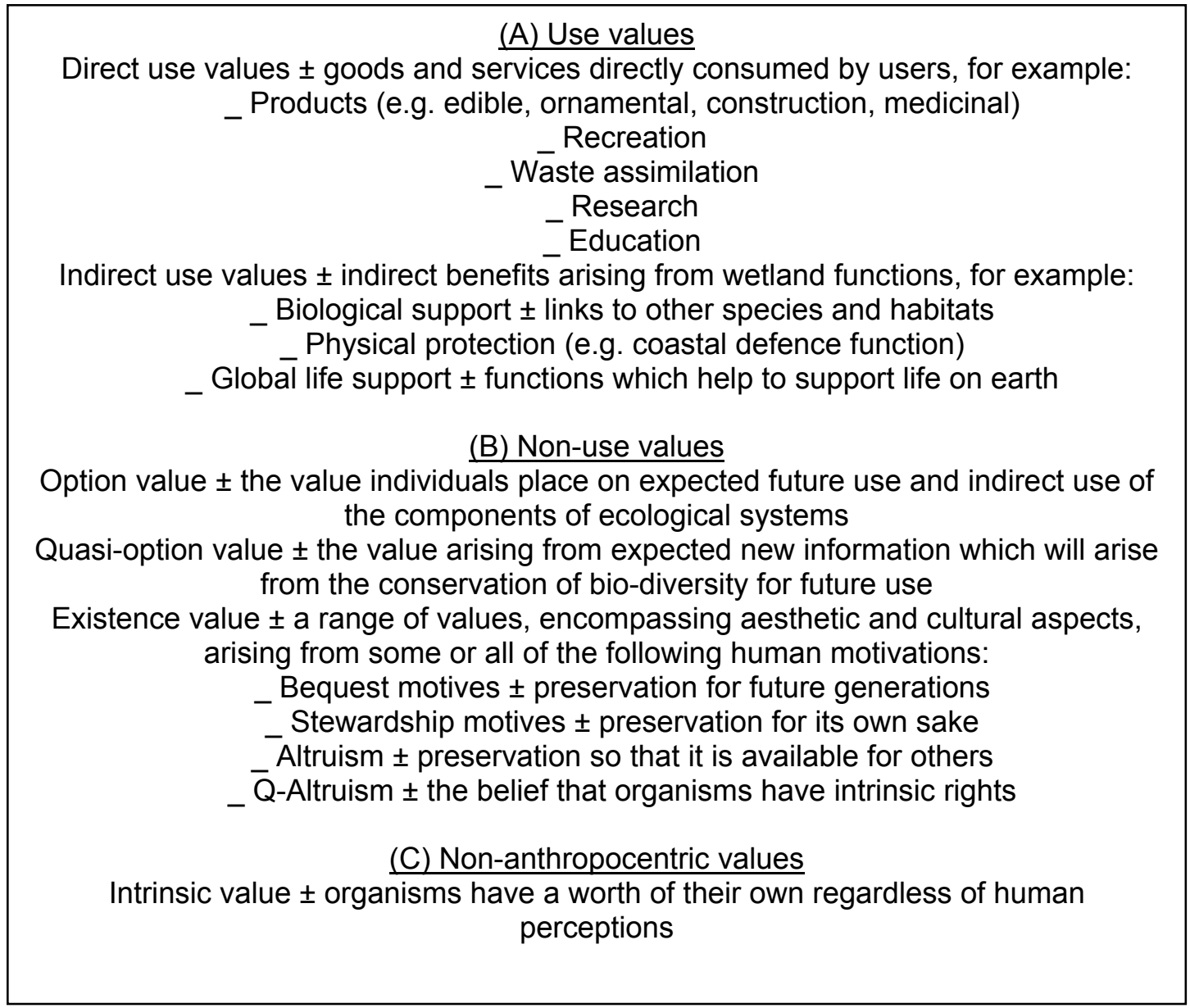

Constructed wetlands are appropriate ecological systems for municipal, industrial, and agricultural wastewater treatment. In 1970s and 1980s, constructed wetlands were built almost exclusively to treat domestic or municipal sewage. Since the 1990s, they have been used for all kinds of wastewater including landfill leachate, runoff (e.g. urban, highway, airport and agricultural), food processing (e.g. winery, cheese and milk production), industrial (e.g. chemicals, paper mill and oil refineries), agricultural operations, mine drainage and sludge dewatering (Vymazal, 2005). They not only have the ability to treat a variety of wastewaters efficiently, but the cost to build and maintain them is relatively low (Hammer, 1989; Meutia, 2001). In such cases, the benefits of the abandoned saltwork to the local 
society are multiple (Figure 3). First of all environmental engineering and management can prevent degradation of the wetland ecosystem that results from point and non-point pollution due to urban, industrial, and agricultural activities in the watershed. In addition, a large part of the wetland area may be restored and maintain its ecological character and importance as a result of improved water quality. Second, part of the saltwork will serve the local society as a low cost and environmentally friendly water treatment method well adapted to the Mediterranean environmental conditions and socioeconomic needs. Third, the saltworks may be used to prevent pollution and subsequent degradation of neighboring coastal ecosystems that are both ecologically sensitive and have major economic value as tourist areas in Mediterranean. Finally, rehabilitation of wetland functions that are associated with food web support and biodiversity, as a result of the water quality improvement, may raise the economic importance of the area. Thus, abandoned and degraded saltworks may be converted into areas of economic activity through promotion of agro/ecotourism and establishment of tourist facilities.

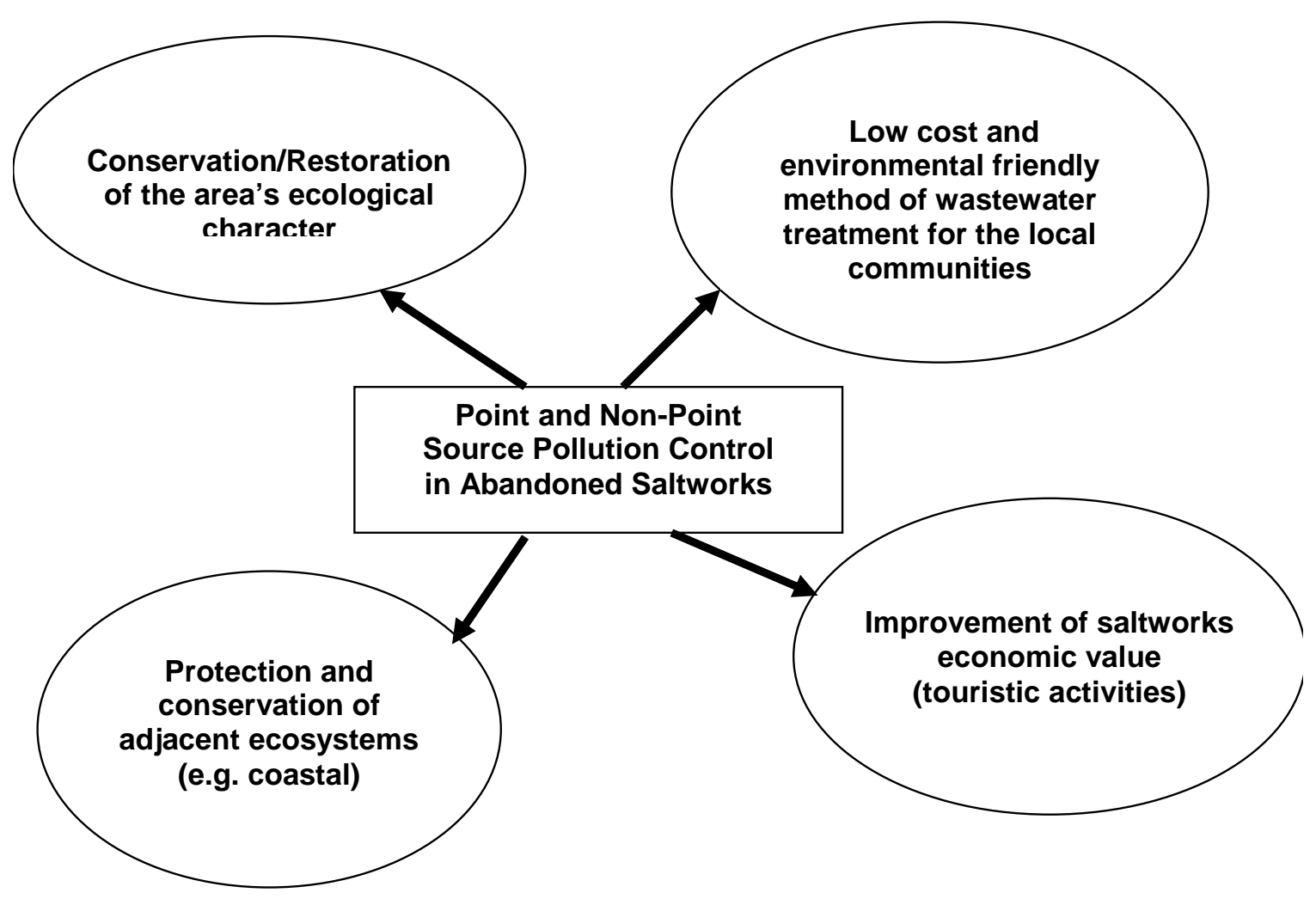

Figure 3. Benefits associated with the rehabilitation of abandoned saltworks for water quality improvement

A recent example comes from the western coast of Portugal, where the estuary of Mondego River supports harbor facilities, industrial activities, salt-works, and aquaculture. Eutrophication became a problem in the Mondego estuary in the 1980 s, presumably as a result of excessive nutrient release into coastal waters. As part of the solution to the problem, it was proposed that both aquaculture and agricultural activities be planned so that nutrient rich waters pass through "constructed" wetlands before entering the estuary directly or via the Pranto River. For aquaculture, it was proposed that the abandoned Salinas adjacent to the estuary might be used for this purpose and would be able to capture most of the organic 
materials and nutrients of aquaculture origin, and at the same time serve as important habitats to the wildlife, especially birds (Joyo et al., 2003).

\section{CONCLUSIONS}

Modern societies have recently undergone profound social changes at all levels, particularly in relation to systems and means of production. As part of these processes, saltworks today constitute a threatened landscape in the Mediterranean and elsewhere. Under these circumstances, and on the assumption that salinas represent more than strictly economic values, the only solution is to preserve their existence and values by applying an alternative type of rehabilitation and management focused on improvement of water quality, while promoting and supporting environmental friendly tourism. However, rehabilitation and use of saltworks in this regard requires careful planning. This must include a continuous loop of biomonitoring and management, with a preparedness to modify management practices in the light of the biological results.

\section{REFERENCES}

1. Barton D.N., (1994), Economic Factors and Valuation of Tropical Coastal Resources, University of Bergen, Norway, Report 14/94.

2. Britton R.H., Johnson A.R., (1987), An ecological account of a Mediterranean salina: The Salinde-Giraud, Camargue (S. France), Biological Conservation, 42, 185-230.

3. Crisman T.L., (1999), Conservation of Mediterranean coastal saline ecosystems: the private sector role in maintaining ecological function. Proceedings of the Post Conference Symposium "SALTWORKS": Preserving Saline Coastal Ecosystems-Global NEST 11-30 Sept 1999, Samos.

4. Do E., (1996), Towards a Methodology for Costing Bio-diversity Targets in the UK, Report to Department of Environment, HMSO.

5. Hammer D.A. (ed.), (1989), Constructed Wetlands for Wastewater Treatment, Municipal, Industrial, and Agricultural. Lewis Publishers Inc., Chelsea, Michigan.

6. Joyo C.M., Nielsen S.N., Pardal M.A. and Jorgensen S.E., (2003), Impact of eutrophication and river management within a framework of ecosystem theories, Ecological Modelling, 166(1-2), 147-168.

7. Kadlec R.H. and Knight R.L., (1996), Treatment wetlands. Lewis Publishers, CRC Press, Boca Raton, Florida.

8. Korovessis N.A., Lekkas T.D., (1999), Solar saltworks production process evolution - wetland function. Proceedings of the Post Conference Symposium SALTWORKS: Preserving Saline Coastal Ecosystems-Global NEST, 11-30 Sept 1999, Samos.

9. Meutia A.A., (2001), Treatment of laboratory wastewater in a tropical constructed wetland comparing surface and subsurface flow, Water Sci. Technol., 44(11-12),499-506.

10. Neves R. (ed.), (2002), Interregional study on restoration of saltworks-ALAS Project. P.51

11. Pearce D.W. and Turner R.K., (1990), Economics of Natural Resources and the Environment, Harvester Wheatsheaf.

12. Petanidou T., (1997), Salt - Salt in European History and Civilisation. Bilingual publication. Hellenic Saltworks S.A., Athens, pp. 380.

13. Petanidou T., (2000), The postmodern saline landscape in Greece and the European Mediterranean: salinas for salt or what?, pp. 67-80, In Korovessis N., Lekkas T.D. (eds.): Saltworks: Preserving saline coastal ecosystems - Proceedings of the Post-Conference Symposium of the 6th International Conference on Environmental Science and Technology, Athens

14. Sadoul N., Walmsley J.G., Charpentier B., (1998). Salinas and nature conservation. MedWet series, Conservation des zones humides mediterraneennes (J. Skinner, A.J. Crivelli, eds.), nA 9, Tourdu Valat, Arles, $96 \mathrm{p}$.

15. Spurgeon J., (1998), The Socio-Economic Costs and Benefits of Coastal Habitat Rehabilitation and Creation, Marine Pollution Bulletin, 37(8-12):373-382. 
16. Vymazal J., (2005), Constructed wetlands for wastewater treatment, Ecological Engineering, 25(5), 475-477.

17. Walmsley J.G., (1999), The ecological importance of Mediterranean salinas. Proceedings of the Post Conference Symposium SALTWORKS: Preserving Saline Coastal Ecosystems-Global NEST, 11-30 Sept 1999, Samos.

18. Zalidis G.C. and Mantzavelas A.L., (1995), Inventory of Greek Wetlands as Natural Resources. Goulandris Natural History Museum and Greek Biotope/Wetland Centre (EKBY). Thessaloniki, Greece. 448 pp. 